\title{
Relationship between soil fertility and plantain nutrition in Cundinamarca (Colombia) with the incidence of two bacterial diseases
}

\section{Relación entre la fertilidad del suelo y la nutrición del plátano en Cundinamarca (Colombia) con la incidencia de dos enfermedades bacterianas}
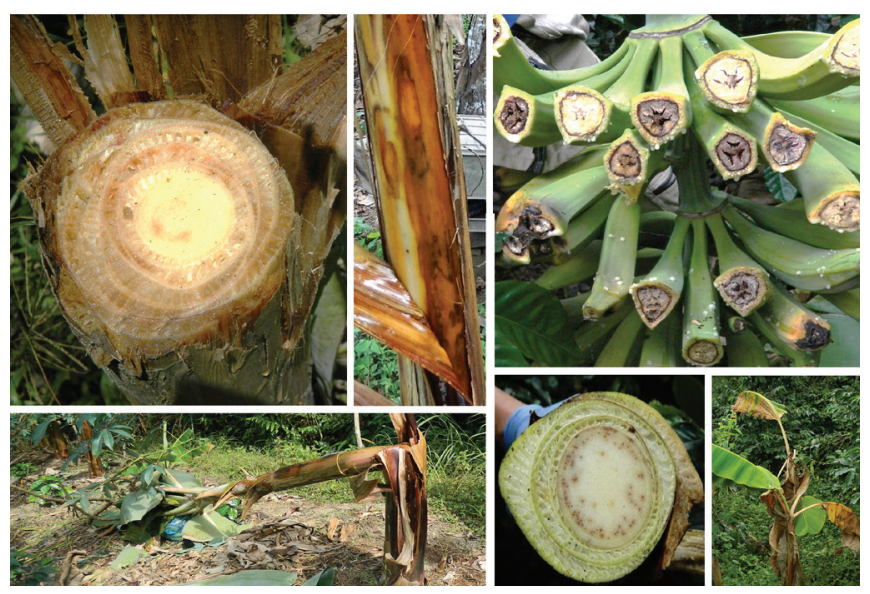

LUIS GABRIEL

BAUTISTA-MONTEALEGRE'1,3

SEBASTIÁN DAVID GARCÍA-GUZMÁN²

MARTHA MARINA

BOLAÑOS-BENAVIDES'

Symptoms of bacteriosis and moko of plantain in the Department of Cundinamarca (Colombia).

Photos: L.G. Bautista-Montealegre,

S.D. García-Guzmán and M.M. Bolaños-Benavides

\begin{abstract}
Bacteriosis and moko of plantain are two of the more important phytosanitary problems in musaceae production in Colombia. To contribute to the management of these diseases in the Department of Cundinamarca, soils and foliar tissues were analyzed, along with symptoms of the diseases on 149 producing farms in the municipalities of Chaguani, La Palma, La Vega, and Viota (Cundinamarca). A descriptive analysis of the chemical properties of the soils and foliar concentration of nutrients was carried out; the Student-Welch $t$-test was applied $(P<0.05)$; the distribution patterns of the diseases were represented cartographically. According to the results, the sampled soils were not saline and had extreme to strong acidity, low effective cation exchange capacity and low fertility; meanwhile, the plants presented a deficit of elements such as nitrogen, phosphorus, sulfur, copper, zinc, and boron. Considering the total number of farms evaluated, the incidence of bacteriosis and moko disease was reported in 63 and 14\% at the departmental level, respectively. A higher concentration of sulfur and zinc was observed in farm soils free of both diseases. Finally, the plants free of bacteriosis showed a higher concentration of potassium and lower concentrations of calcium and manganese, while the plants free of moko disease showed higher concentrations of nitrogen, sodium, and copper and a lower concentration of calcium. The results can contribute to the planning of large-scale management strategies to reduce the risk of the dissemination of diseases of economic importance for plantain crops.
\end{abstract}

Corporación Colombiana de Investigación Agropecuaria (Agrosavia), Centro de Investigación Tibaitata, Mosquera (Colombia). ORCID Bautista-Montealegre, L.G.: 0000-0001-9305-5630; ORCID Bolaños-Benavides, M.M.: 0000-0003-4593-5523

2 Universidad Nacional de Colombia, Bogota (Colombia). ORCID García-Guzmán, S.D.: 0000-0001-8739-3334

3 Corresponding author. lbautista@agrosavia.co 


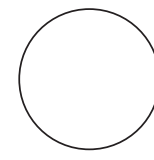

Additional key words: Dickeya sp.; Ralstonia solanacearum; incidence; Dominic Hartón; soil properties; leaf tissue analysis.

\section{RESUMEN}

La bacteriosis y el moko de plátano son considerados como uno de los problemas fitosanitarios más importantes en la producción de musáceas en Colombia. Para contribuir al manejo de dichas enfermedades en el departamento de Cundinamarca, se analizaron suelos y tejidos foliares, así como los síntomas de las enfermedades en 149 fincas de productores de los municipios de Chaguaní, La Palma, La Vega y Viotá. Se llevó a cabo un análisis descriptivo de las propiedades químicas de los suelos y concentración foliar de nutrientes, se aplicó la prueba $t$ de Student-Welch $(P \leq 0,05)$, y se representaron cartográficamente los patrones de distribución de las enfermedades. Según los resultados obtenidos, los suelos muestreados no son salinos, presentan acidez extrema a fuerte, baja capacidad de intercambio catiónico efectiva, y baja fertilidad; mientras que las plantas mostraron déficit de elementos como nitrógeno, fósforo, azufre, cobre, zinc y boro. Considerando el número de fincas evaluadas, se reportó una incidencia de bacteriosis y moko de 63 y 14\%, respectivamente. Se observó mayor concentración de azufre y zinc en suelos de fincas libres de ambas enfermedades. Finalmente, plantas reportadas como sanas de bacteriosis arrojaron mayor concentración de potasio y menores concentraciones de calcio y manganeso; mientras que plantas reportadas como sanas de moko, mostraron mayor concentración de nitrógeno, sodio y cobre, y menor concentración de calcio. Los resultados obtenidos contribuyen en la planificación de estrategias de manejo a gran escala, con el fin de disminuir el riesgo de diseminación de enfermedades de importancia económica para el cultivo de plátano.

Palabras clave adicionales: Dickeya sp.; Ralstonia solanacearum; incidencia; Dominic Hartón; propiedades del suelo; análisis de tejido foliar.

Received for publication: 17-06-2019 Accepted for publication: 30-03-2020

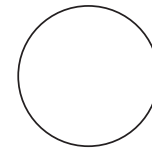

In 2019, Colombia produced 4,376,922 t of plantain and reported a cultivation area of 450,329 ha, with Arauca as the leading producer department, followed by the departments of Antioquia, Meta, and Valle del Cauca. Cundinamarca ranked $12^{\text {th }}$ with a cultivated area of 12,234 ha and a production of 102,350 t (Agronet, 2020).

Phytosanitary problems in any crop cause a decrease in production, a reduction in the quality of the final product, and, in extreme cases, depending on the causal agent, a total loss of the plantation crop. Plantain production in Colombia is exposed to phytosanitary problems as the result of the attack of fungi, bacteria, viruses, and phytoparasitic nematodes, among others. In this sense, bacteriosis or wet rot and moko are caused by the bacterial species Dickeya sp. and Ralstonia solanacearum Race 2, respectively.

Dickeya sp. degrades tissues and releases cellular fluids that attract secondary bacteria, which proliferate in the cells and often release unpleasant odors. Pathogens that cause soft rot secrete extracellular enzymes, such as pectate lyases, cellulases, nucleases, and proteases, that degrade pectin, cellulose, nucleic acid, and cellular proteins, respectively (Kado, 2016a). This species survives mainly in the tissue of diseased plants, crop residues, soil and compost (Kado, 2016a); it generally appears during the summer season, generating losses of up to $100 \%$ on plantations where adequate management measures are not implemented (Aránzazu et al., 2002). Initially, plants affected by bacteriosis show necrosis at the edge of the oldest leaves, which progresses to the entire leaf blade, causing total chlorosis (Alarcón and Jiménez, 2012). If the bacterium spreads rapidly, the plant dies with its brown, dead leaves remaining erect, and the older leaves often fall while green, with the younger center leaves turning yellow (Jones, 2018). However, in Colombia, the primary symptomatology is observed in the pseudostem, where aqueous rot develops, accompanied by translucent spots with a yellowish color at 
the beginning that later turn reddish to dark brown. This weakens the middle part of the plant, accompanied by a strong foul odor that attracts pests (weevils), aggravating the problem by disseminating the bacterium on the plantation (Aránzazu et al., 2002; Alarcón and Jiménez, 2012).

On the other hand, $R$. solanacearum Race 2 is one of the more destructive bacteria in the world, with a negative impact on banana and plantain production systems in the tropics and warm temperate zones (Kado, 2016b). In Colombia, losses generated by attack of this bacterium in musaceas can range up to $100 \%$ since the fruits are severely affected; moreover, higher management costs are related to the application of eradication measures and quarantine times (Yabuuchi et al., 1992; Castañeda and Espinosa, 2005; Bejarano, 2010). In plantain cultivation, this bacterium attacks in any physiological state of the plant, moving downwards through mechanical damage caused by an infected tool or by insect attack on the branch or upwards when penetrating the root system or pseudostem through wounds (Hurtado, 2012). Once inside the tissue, the vascular parenchyma and the xylem get infected, and exopolysaccharides (acidic extracellular polysaccharide - EPS I) and

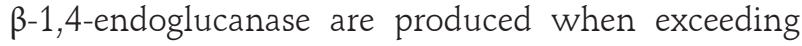
$10^{7}$ cells $/ \mathrm{mL}$, promoting bacterial colonization of the plant (Kado, 2016b), vascular bundle blockage, weakening through water and nutrient deficiency, wilting, and, finally, plant death.

According to Álvarez et al. (2015), in newly planted seedlings affected by moko disease, widespread yellowing appears with subsequent necrosis and when the pseudostem is cut, and a few reddish spots or brown lines appear, corresponding to the vascular bundles where the pathogenic bacterium has degraded tissues. In young plants, dry leaves appear in the middle of asymptomatic leaves or the flag leaf appears completely necrosed. When cutting the rachis, fruits, pseudostem, or corms, internal damage can be observed as lesions that are, at first, pale yellow, becoming reddish brown, and then black. When attack is late or transmission is by vector insects to the bunch, reddish or black coloration appears in the affected plantain fingers; upon cutting across the rachis, spots can be seen, corresponding to infected vascular bundles through which the bacterium has moved throughout the plant.

The integrated management of these two diseases involves prevention measures, such as disinfection of tools and footwear, weed control, and use of healthy seeds. Furthermore, the implementation of cultural practices, such as removing dry leaf sheaths, management of the weevils-worm screws complex, and, after identifying symptoms on plantations, zoning the plots and implementing the management schemes recommended by Corporación Colombiana de Investigación Agopecuaria - AGROSAVIA (Formerly CORPOICA), CIAT and ICA (Aránzazu et al., 2002; Álvarez et al., 2007, 2013; Alarcón and Jiménez, 2012). Additionally, managing phytosanitary problems as reported by other authors in Colombia (Aránzazu et al., 2002; Alarcón and Jiménez, 2012; Ramírez et al., 2014; Bautista-Montealegre et al., 2016) requires analyzing plant nutrition and soil fertility in pathogenplant interactions.

In accordance with the latter, adequate crop nutrition contributes to a reduction of disease attacks (Méndez and Viteri, 2007; Viteri et al., 2012; BautistaMontealegre et al., 2017) and is directly related to the occurrence of plant resistance and predisposition factors according to nutritional imbalances (Chaboussou, 1967). Deficiencies in crop nutrition can increase susceptibility to various diseases and, therefore, increase aggressiveness seen in weak infections (Huber, 1997; Velasco, 2000; McMahon, 2012).

Accordingly, the aim of this study was to analyze the incidence of bacteriosis and moko diseases in the plantain cultivar Dominico Harton (Musa AAB Simmonds) in four producing municipalities in the Department of Cundinamarca and its relationship with chemical soil properties and foliar nutrient concentrations.

\section{MATERIALS AND METHODS}

This study was carried out in the municipalities of Chaguani, La Palma, La Vega and Viota, located in the Department of Cundinamarca. The latter is located in the Andean region, on the eastern mountain range (Cordillera) of the Colombian central area, between $3^{\circ} 42^{\prime}-5^{\circ} 51^{\prime} \mathrm{N}$ and $73^{\circ} 3^{\prime}-74^{\circ} 54^{\prime} \mathrm{W}$ (IGAC, 1999). One hundred forty-nine (149) previously selected plantain farms were visited and georeferenced with a Global Positioning System (GPS) (Garmin ${ }^{\circledR}$ brand). These farms are in areas that register average temperatures of 16 to $26^{\circ} \mathrm{C}$, precipitation of 900 to $2750 \mathrm{~mm}$ year ${ }^{-1}$, relative humidity of 75 to $85 \%$ (AGROSAVIA, 2020) and altitudes of 1,121 to 1,770 $\mathrm{m}$ a.s.1. (Tab. 1). 
Table 1. Biophysical characteristics of the territory and number of plantain farms visited by municipality in the Department of Cundinamarca.

\begin{tabular}{|c|c|c|c|c|c|}
\hline Municipality & Temperature $\left({ }^{\circ} \mathrm{C}\right)$ & $\begin{array}{l}\text { Precipitation } \\
\left(\text { mm year }^{-1}\right)\end{array}$ & $\begin{array}{c}\text { Humidity } \\
(\%)\end{array}$ & $\begin{array}{l}\text { Altitude } \\
\text { (m a.s.l.) }\end{array}$ & Farms visited \\
\hline Viotá & $16-26$ & $900-1750$ & $75-85$ & $1202-1617$ & 53 \\
\hline La Vega & $16-22$ & $2000-2750$ & $80-85$ & $1500-1770$ & 43 \\
\hline Chaguani & $16-24$ & $1300-2000$ & $75-85$ & $1121-1848$ & 29 \\
\hline La Palma & $18-24$ & $1750-2500$ & $80-85$ & $1305-1640$ & 24 \\
\hline Total & & & & & 149 \\
\hline
\end{tabular}

The incidence of bacteriosis and moko diseases in the department was calculated from visual observation in the field of internal and external symptoms of randomly selected plants, qualifying the farms as healthy or sick according to the presence of characteristic symptoms described by Aránzazu et al. (2002), Alarcón and Jiménez (2012) and Álvarez et al. (2015).

Moreover, soil samples were collected from each farm according to the methodology described by Bolaños (2006) for chemical analysis. Plant tissue samples were obtained by taking $10 \mathrm{~cm}$ at the middle of the third leaf from the flag leaf on each farm for nutrient concentration analysis. The collected samples were processed according to the protocols of the analytical chemistry laboratory of AGROSAVIA at the Tibaitata Research Center in Mosquera (Cundinamarca), following norm NTC ISO/IEC 17025.

Once the laboratory results were obtained, a descriptive analysis of the chemical properties of the soil and the foliar concentration of nutrients was carried out by analyzing the range frequency according to the classification published by ICA (1992), along with the macro and micronutrient approximations in foliar tissues by Munson (1998). Additionally, the data were subjected to comparison of means for independent groups using the $t$-Student-Welch test with a level of significance of $P<0.05$. Finally, ArcGIS 10.3 (ESRI ${ }^{\circledR}$ ) was used according to the sampling carried out to cartographically represent the distribution patterns of the diseases in the field.

\section{RESULTS AND DISCUSSION}

\section{Incidence of Dickeya sp. and $\boldsymbol{R}$. solanacearum}

Of the total number of farms evaluated in four municipalities, 63 and 14\% of these farms were affected by bacteriosis and moko, respectively. In the case of bacteriosis, a higher number of sick plants were observed on farms in the municipalities of La Vega and Viota, followed by the municipalities of Chaguani and La Palma, with reports of 36, 25, 18 and 16 farms, respectively. However, the incidence of the disease was higher in the municipalities of Viota and La Palma, with 68 and $67 \%$, followed by the municipalities of Chaguani and La Vega with 62 and 50\%, respectively (Fig. 1).
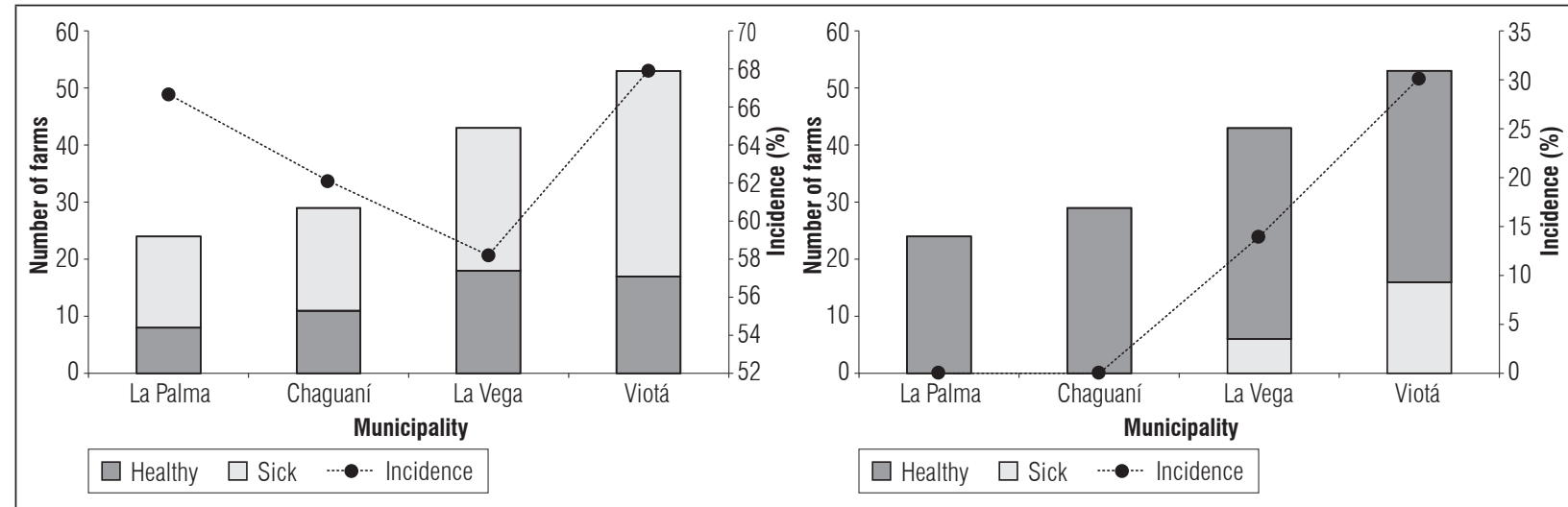

Figure 1. Number of plantain farms per municipality affected by bacteriosis (left) and moko (right). 
On the other hand, more plants were observed on farms affected by moko in the municipalities of Viota and La Vega, with 16 and 6, respectively, while the municipalities of La Palma and Chaguani did not report the presence of this disease. Hence, the incidence was higher in the municipality of Viota with $30 \%$, followed by the municipality of La Vega with 14\% (Fig. 1).

In the municipality of Chaguani, the presence of bacteriosis was confirmed on the eastern edge of the municipality in the veredas (settlements) Llanadas, Montefrio, and El Rincon, while, in the municipality of La Palma, the majority of the farms reported bacteriosis in the southern part of the municipality (Fig. 2).
The plantations affected by bacteriosis in the municipality of La Vega were concentrated in settlement El Chupal, with isolated cases in settlement Hoya Grande, while the presence of moko on the plantations was on the northern edge of settlement Naguy, and only one case was found in the southwest of settlement El Chupal (Fig. 2).

Finally, in the municipality of Viota, settlement Bajo Ceilan reported a higher number of plantations affected by both diseases; additionally, in this settlement, there were several farms with the presence of only one of the diseases. Both in Bajo Palmar and Mogambo, the most prevalent phytosanitary problem was bacteriosis, which was concentrated in the southern part (Fig. 2).

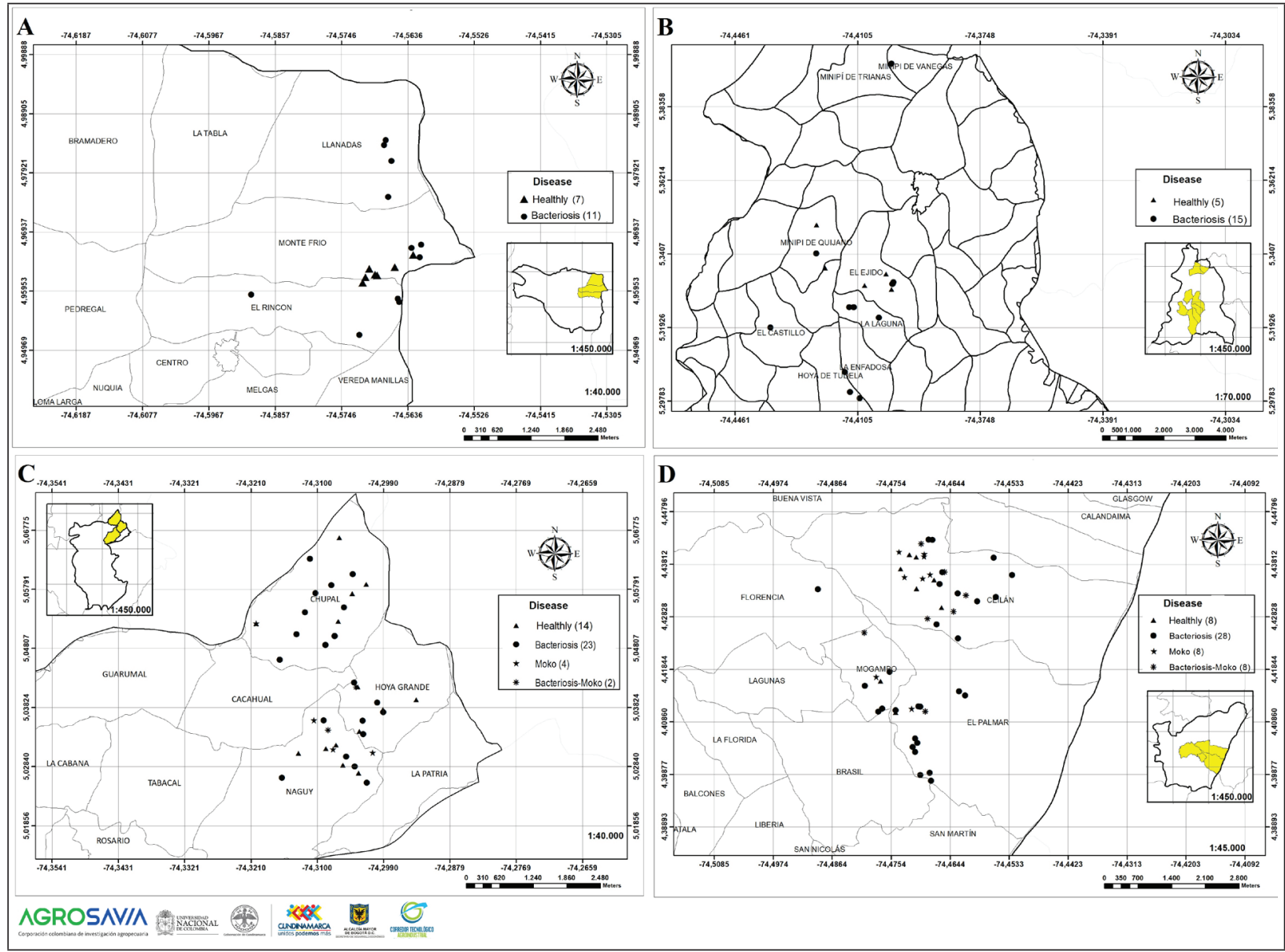

Figure 2. Spatial distribution of the bacterial diseases bacteriosis and moko on the Dominico-Harton plantain farms in the municipalities of Chaguani (A), La Palma (B), La Vega (C) and Viota (D), in the Department of Cundinamarca. Source: The authors. 
The diseases evaluated in the municipalities did not show a defined distribution pattern (Fig. 2), and their dispersion was possibly influenced by specific epidemiological aspects of each pathogen, as well as by biophysical and sociocultural conditions and crop management techniques. The epidemiology of the diseases, in the case of bacteriosis, was focused on the endemic nature of the bacterium and its ability to develop and establish in a wide range of temperatures (i.e., 5, 22 and $37^{\circ} \mathrm{C}$ for minimum, optimum and maximum temperatures, respectively), as well as long periods of drought alternated with heavy rains (Alarcón and Jiménez, 2012), particularly if the ground is poorly drained, cool, and plants are waterlogged (Jones, 2018). Furthermore, other factors that stand out are the survival of the pathogen in alternate hosts and plant debris that remain attached to the pseudostem as the result of defoliation (Martínez and García, 2003), high incidence of insects such as Metamasius hemipterus L. (Coleoptera: Curculionidae) and nutritional imbalances, especially considering elements such as potassium and boron (Belalcázar, 1991; Bolaños-Benavides and Benalcázar-Carvajal, 2000; Aránzazu et al., 2002).

For moko in plantain, although its incidence in the municipalities was low (14\%), its prevalence and spread to new areas or farms is possible because of transmission by insect vectors and movement of infected material from other affected areas (Álvarez et al., 2015). According to a study carried out by Cardona et al. (2017) in which technical and socioeconomic particularities of the productive system were established in the same municipalities studied in the instant research, non-disinfestation of tools, highly variable disease management strategies and use of seeds from the same farm are related to the presence of bacteriosis and moko in plantain. This translates into a constant threat to plantain production in producing areas, particularly since management decisions are made based on traditional knowledge or the recommendation of other farmers.

\section{Chemical soil properties and foliar nutrient concentrations}

According to the descriptive analysis of the chemical characteristics of all soils sampled (Tab. 2), the results were: a higher frequency of extreme to strong acidity (44-46\%, respectively); low effective cation exchange capacity (63\%); non-saline soils for electrical conductivity of less than two (100\%); very low sodium content (63\%); low levels of phosphorus $(46 \%)$, magnesium (54\%), copper (54\%), boron (59\%), calcium $(42 \%)$, manganese $(49 \%)$, potassium $(39 \%)$ and the magnesium potassium ratio (68\%); sufficient zinc content $(49 \%)$ as well as high sulfur content $(61 \%)$, and high values for calcium/magnesium, calcium/ boron and calcium/magnesium + potassium ratios (71, 98 and $62 \%$, respectively); moreover, there were very high contents of organic matter (46\%) and iron $(67 \%)$ and low to very high aluminum concentration frequencies (37\%).

The nutrient concentration in foliar tissue collected to evaluate bacteriosis and moko on the plantain farms (Tab. 3 and Tab. 4, respectively) showed frequent deficits of nitrogen (61 and $62 \%$, respectively), phosphorus (60 and $63 \%$, respectively), sulfur (82 and $84 \%$, respectively), copper (92 and $95 \%$, respectively), zinc ( 95 and 97\%, respectively) and boron (90 and 69\%, respectively). The plantain foliar tissue showed normal concentrations of calcium (94 and $86 \%$, respectively), potassium (91 and 88\%, respectively), iron (96 and $86 \%$, respectively), magnesium (62 and 63\%, respectively) and manganese (65 and $60 \%$, respectively).

However, the student's t-test, used to compare the health of the crops on the farms and the chemical properties of the soil, showed statistically significant differences $(P<0.05)$ in the content of sulfur affected by bacteriosis (8.28) and in the content of zinc (4.17) affected by moko; these values were low when compared with the concentration in the farm soils without the diseases (S: 10.36 and Zn: 6.37) (Tab. 5). 


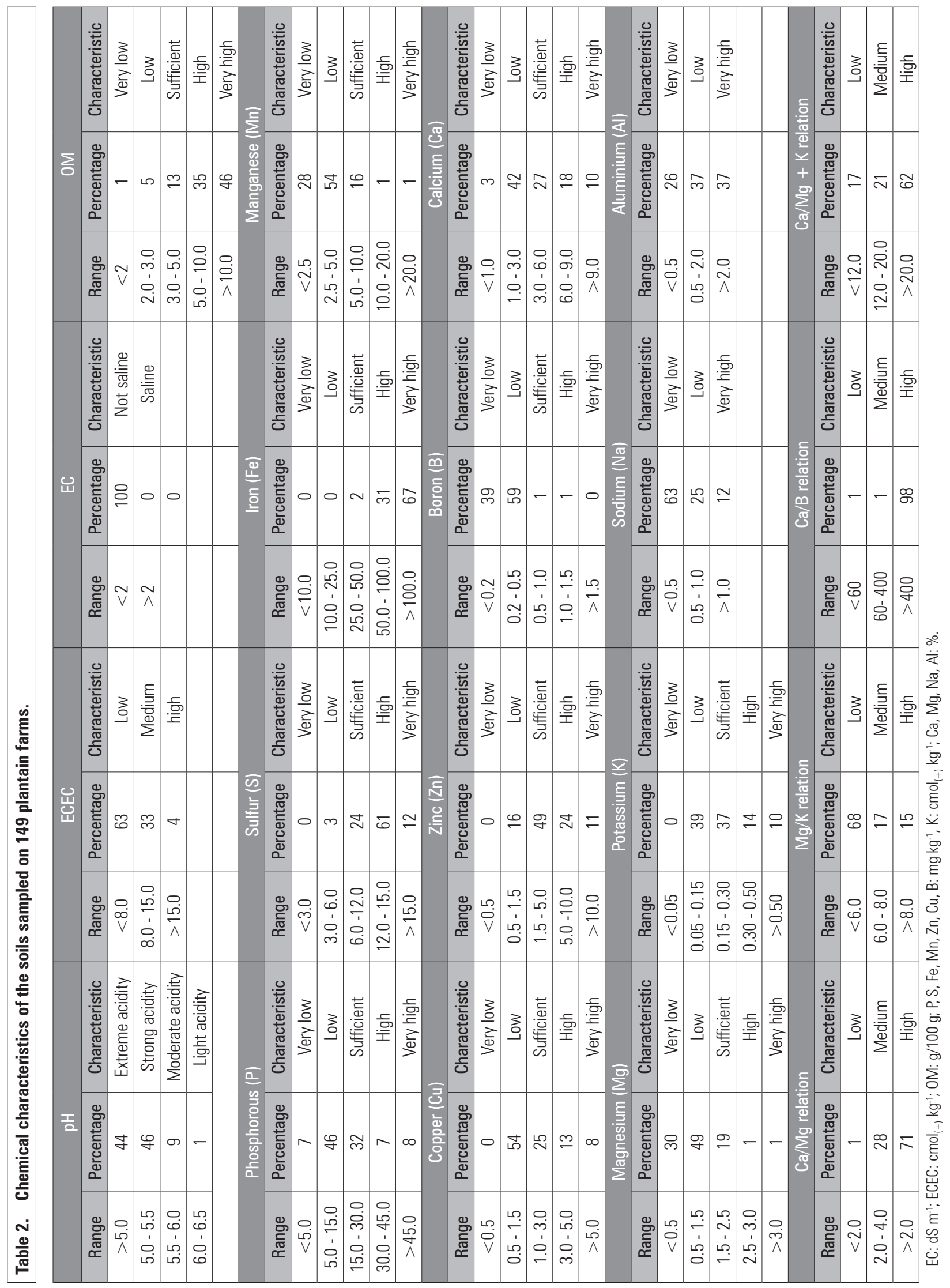


Table 3. Approximate concentration ranges of macro and micronutrients in foliar tissues of plants evaluated for bacteriosis symptoms on 149 plantain farms.

\begin{tabular}{|c|c|c|c|c|c|c|c|c|}
\hline \multicolumn{3}{|c|}{ Nitrogen (N) } & \multicolumn{3}{|c|}{ Phosphorous (P) } & \multicolumn{3}{|c|}{ Potassium (K) } \\
\hline Range & Percentage & Characteristic & Range & Percentage & Characteristic & Range & Percentage & Characteristic \\
\hline$<2.5$ & 61 & Deficit & $<0.15$ & 60 & Deficit & $<1.0$ & 8 & Deficit \\
\hline $2.5-4.5$ & 39 & Normal & $0.20-0.75$ & 40 & Normal & $1.5-5.5$ & 91 & Normal \\
\hline$>6.0$ & 0 & Excess & $>1.0$ & 0 & Excess & $>6.0$ & 1 & Excess \\
\hline \multicolumn{3}{|c|}{ Calcium (Ca) } & \multicolumn{3}{|c|}{ Magnesium (Mg) } & \multicolumn{3}{|c|}{ Sulfur (S) } \\
\hline Range & Percentage & Characteristic & Range & Percentage & Characteristic & Range & Percentage & Characteristic \\
\hline$<0.5$ & 16 & Deficit & $<0.2$ & 38 & Deficit & $<0.2$ & 82 & Deficit \\
\hline $1.0-4.0$ & 84 & Normal & $0.25-1.0$ & 62 & Normal & $0.25-1.0$ & 18 & Normal \\
\hline$>5.0$ & 0 & Excess & $>1.50$ & 0 & Excess & $>3.0$ & 0 & Excess \\
\hline \multicolumn{3}{|c|}{ Iron (Fe) } & \multicolumn{3}{|c|}{ Copper (Cu) } & \multicolumn{3}{|c|}{ Manganese (Mn) } \\
\hline Range & Percentage & Characteristic & Range & Percentage & Characteristic & Range & Percentage & Characteristic \\
\hline$<5$ & 4 & Deficit & $2.0-5.0$ & 92 & Deficit & $15-25$ & 4 & Deficit \\
\hline $100-500$ & 96 & Normal & $5.0-30$ & 8 & Normal & $20-300$ & 65 & Normal \\
\hline$>500$ & 0 & Excess & $30-100$ & 0 & Excess & $300-500$ & 31 & Excess \\
\hline \multicolumn{3}{|c|}{ Zinc (Zn) } & \multicolumn{3}{|c|}{ Boron (B) } & & & \\
\hline Range & Percentage & Characteristic & Range & Percentage & Characteristic & & & \\
\hline $1.0-20$ & 95 & Deficit & $5.0-30$ & 90 & Deficit & & & \\
\hline $27-100$ & 5 & Normal & $30-200$ & 10 & Normal & & & \\
\hline $100-400$ & 0 & Excess & $50-200$ & 0 & Excess & & & \\
\hline
\end{tabular}

$\mathrm{N}, \mathrm{P}, \mathrm{K}, \mathrm{Ca}, \mathrm{Mg}, \mathrm{Na}$, and S: \%. Fe, Cu, Mn, Zn and B: $\mathrm{mg} \mathrm{kg}^{-1}$.

Table 4. Approximate concentration ranges of macro and micronutrients in foliar tissues of total plants evaluated for moko symptoms on 149 plantain farms.

\begin{tabular}{|c|c|c|c|c|c|c|c|c|}
\hline \multicolumn{3}{|c|}{ Nitrogen (N) } & \multicolumn{3}{|c|}{ Phosphorous (P) } & \multicolumn{3}{|c|}{ Potassium (K) } \\
\hline Range & Percentage & Characteristic & Range & Percentage & Characteristic & Range & Percentage & Characteristic \\
\hline$<2.5$ & 62 & Deficit & $<0.15$ & 63 & Deficit & $<1.00$ & 12 & Deficit \\
\hline $2.5-4.5$ & 37 & Normal & $0.20-0.75$ & 37 & Normal & $1.5-5.5$ & 88 & Normal \\
\hline$>6.0$ & 1 & Excess & $>1.0$ & 0 & Excess & $>6.0$ & 0 & Excess \\
\hline \multicolumn{3}{|c|}{ Calcium (Ca) } & \multicolumn{3}{|c|}{ Magnesium (Mg) } & \multicolumn{3}{|c|}{ Sulfur (S) } \\
\hline Range & Percentage & Characteristic & Range & Percentage & Characteristic & Range & Percentage & Characteristic \\
\hline$<0.5$ & 14 & Deficit & $<0.2$ & 37 & Deficit & $<0.2$ & 84 & Deficit \\
\hline $1,0-4.0$ & 86 & Normal & $0.25-1.0$ & 63 & Normal & $0.25-1.0$ & 16 & Normal \\
\hline$>5.0$ & 0 & Excess & $>1.5$ & 0 & Excess & $>3.0$ & 0 & Excess \\
\hline \multicolumn{3}{|c|}{ Iron (Fe) } & \multicolumn{3}{|c|}{ Copper (Cu) } & \multicolumn{3}{|c|}{ Manganese (Mn) } \\
\hline Range & Percentage & Characteristic & Range & Percentage & Characteristic & Range & Percentage & Characteristic \\
\hline$<50.0$ & 14 & Deficit & $2.0-5.0$ & 95 & Deficit & $15-25$ & 3 & Deficit \\
\hline $100-500$ & 86 & Normal & $5.0-30.0$ & 4 & Normal & $20-300$ & 60 & Normal \\
\hline$>500$ & 0 & Excess & $30.0-100.0$ & 1 & Excess & $300-500$ & 37 & Excess \\
\hline \multicolumn{3}{|c|}{ Zinc $(Z n)$} & \multicolumn{3}{|c|}{ Boron (B) } & & & \\
\hline Range & Percentage & Characteristic & Range & Percentage & Characteristic & & & \\
\hline $1.0-20.0$ & 97 & Deficit & $5.0-30.0$ & 69 & Deficit & & & \\
\hline $27.0-100.0$ & 3 & Normal & $30.0-200.0$ & 31 & Normal & & & \\
\hline $100.0-400.0$ & 0 & Excess & $50.0-200.0$ & 0 & Excess & & & \\
\hline
\end{tabular}

$\mathrm{N}, \mathrm{P}, \mathrm{K}, \mathrm{Ca}, \mathrm{Mg}, \mathrm{Na}$, and S: \%. Fe, Cu, Mn, Zn and B: $\mathrm{mg} \mathrm{kg}^{-1}$. 
Table 5. Chemical soil properties from 149 plantain farms according to the presence and absence of bacteriosis and moko.

\begin{tabular}{|c|c|c|c|c|c|c|c|c|c|c|}
\hline \multicolumn{11}{|c|}{ Bacteriosis } \\
\hline State & $\mathrm{pH}$ & $\mathrm{EC}$ & ECEC & $\mathrm{OM}$ & $\mathrm{P}$ & $S^{*}$ & K & $\mathrm{Fe}$ & $\mathrm{Mn}$ & $\mathrm{Zn}$ \\
\hline Sick & 5.0 & 0.33 & 7.55 & 8.99 & 19.40 & 8.28 & 0.22 & 307.01 & 3.95 & 5.63 \\
\hline Healthy & 5.2 & 0.34 & 8.74 & 9.50 & 30.87 & 10.36 & 0.32 & 330.93 & 4.42 & 6.74 \\
\hline State & $\mathrm{Cu}$ & B & Sat_Ca & Sat_Mg & Sat_Na & Sat_Al & $\mathrm{Ca} / \mathrm{Mg}$ & $\mathrm{Ca}+\mathrm{Mg} / \mathrm{K}$ & $\mathrm{Mg} / \mathrm{K}$ & $\mathrm{Ca} / \mathrm{B}$ \\
\hline Sick & 2.63 & 0.23 & 52.02 & 11.53 & 6.11 & 29.26 & 4.63 & 28.97 & 5.21 & 4,718 \\
\hline Healthy & 2.56 & 0.25 & 52.02 & 11.53 & 6.11 & 29.26 & 4.77 & 29.22 & 5.43 & 5,103 \\
\hline \multicolumn{11}{|c|}{ Moko disease } \\
\hline State & $\mathrm{pH}$ & EC & ECEC & $\mathrm{OM}$ & $\mathrm{P}$ & S & K & $\mathrm{Fe}$ & $\mathrm{Mn}$ & $\mathrm{Zn}^{*}$ \\
\hline Sick & 5.2 & 0.31 & 8.54 & 9.61 & 20.26 & 9.27 & 0.27 & 299.14 & 3.78 & 4.17 \\
\hline Healthy & 5.0 & 0.33 & 7.88 & 9.09 & 24.16 & 8.99 & 0.25 & 318.70 & 4.18 & 6.37 \\
\hline State & $\mathrm{Cu}$ & $\mathrm{B}$ & Sat_Ca & Sat_Mg & Sat_Na & Sat_Al & $\mathrm{Ca} / \mathrm{Mg}$ & $\mathrm{Ca}+\mathrm{Mg} / \mathrm{K}$ & $\mathrm{Mg} / \mathrm{K}$ & $\mathrm{Ca} / \mathrm{B}$ \\
\hline Sick & 2.73 & 0.29 & 60.73 & 13.30 & 5.29 & 18.91 & 4.70 & 28.67 & 5.36 & 4,756 \\
\hline Healthy & 2.58 & 0.23 & 60.73 & 13.30 & 5.29 & 18.91 & 4.68 & 29.14 & 5.27 & 4,876 \\
\hline
\end{tabular}

EC: dS m ${ }^{-1}$; CICE: $\mathrm{cmol}_{(+)} \mathrm{kg}^{-1} ;$ OM: g/100 g; P, S, Fe, Mn, Zn, Cu, B: $\mathrm{mg} \mathrm{kg}^{-1}, \mathrm{~K}^{-} \mathrm{cmol}(+) \mathrm{kg}^{-1}$; Sat_Ca, Sat_Mg, Sat_Na, Sat_Al: \%.

$*$ : Significant at $P<0.05$

As seen in the soil results and the importance of its availability for plants, $\mathrm{S}$ is a constituent of proteins and amino acids, such as cysteine and methionine; these amino acids are precursors of other compounds that contain this element, such as coenzymes and plant subproducts, which are directly involved in metabolic reactions (Hawkesford et al., 2012). This element has been recognized in the control of diseases through its use as a fungicide, which was initially implemented in the agricultural sector in 1847 for the control of Oidium in vineyards (Paul, 1978). Further, for vascular diseases, researchers have demonstrated that levels of $\mathrm{S}$ accumulation in vascular tissue were fungitoxic for Verticillium dahliae in tomato plants, inhibiting spore germination and growth of fungal hyphae (Williams et al., 2002), whilst, in tobacco and French bean susceptible to Fusarium oxysporum and tomato susceptible to $R$. solanacearum, sulphur was detected in xylem excised from infected plants but not in controlled plants (Williams and Cooper, 2003).

$\mathrm{Zn}$ is the second most abundant transition metal in living organisms, after Fe; the metabolic functions of $\mathrm{Zn}$ are based on its strong tendency to form tetrahedral complexes with $\mathrm{N}, \mathrm{O}$, and, mainly, S ligands, playing a functional and structural role in enzymatic reactions. Additionally, it is related to protein molecules involved in DNA replication and the regulation of gene expression. Further, the metabolic changes induced by a $\mathrm{Zn}$ deficiency are complex. However, some can be explained by the functions of this element in enzymatic and metabolic reactions, so when they affect the expression and regulation of defense mechanisms of genes and proteins, $\mathrm{Zn}$ contributes to the tolerance of plants to environmental stressors (Broadley et al., 2012).

In the foliar tissue, the concentration of nutrients showed significant differences $(P<0.05)$ for $\mathrm{K}, \mathrm{Ca}$ and $\mathrm{Mn}$ in the plants with bacteriosis, while the plants with symptoms of moko had differences in the concentrations of $\mathrm{N}, \mathrm{Ca}, \mathrm{Na}$ and $\mathrm{Cu}$ (Tab. 6). The plants free of bacteriosis showed a higher concentration of $\mathrm{K}$ and lower concentrations of $\mathrm{Ca}$ and $\mathrm{Zn}$, while the plants free of moko showed higher concentrations of $\mathrm{N}, \mathrm{Na}$ and $\mathrm{Cu}$ and a lower concentration of $\mathrm{Ca}$ (Tab. 6).

Bacteria such as Dickeya sp. that produce soft rot release polygalacturonase and pectolytic enzymes as they spread within the tissues of the host, while vascular diseases such as moko caused by $R$. solanacearum spread within plants through the xylem and lead to the formation of "slime" that clogs the vessels (Huber et al., 2012). Calcium and manganese are related to the resistance of plants to bacterial diseases through stabilization of the medium lamella, inhibition the formation of pectolytic enzymes and decrease in accumulation of sugars and amino acids in the apoplast in the case of $\mathrm{Ca}$, along with hypersensitivity 
Table 6. Foliar nutrient concentration from 149 plantain farms according to the presence and absence of bacteriosis and moko.

\begin{tabular}{|l|c|c|c|c|c|c|c|c|c|c|c|c|c|}
\hline \multicolumn{10}{|c|}{ Bacteriosis } \\
\hline State & $\mathrm{N}$ & $\mathrm{P}$ & $\mathrm{K}^{*}$ & $\mathrm{Ca}^{*}$ & $\mathrm{Mg}$ & $\mathrm{Na}$ & $\mathrm{S}$ & $\mathrm{Fe}$ & $\mathrm{Cu}$ & $\mathrm{Mn}^{*}$ & $\mathrm{Zn}$ & $\mathrm{B}$ \\
\hline Sick & 2.37 & 0.13 & 1.66 & 1.23 & 0.231 & 0.007 & 0.16 & 82.69 & 3.53 & 450 & 14.88 & 17.93 \\
\hline Healthy & 2.46 & 0.14 & 2.02 & 0.88 & 0.243 & 0.008 & 0.16 & 88.48 & 4.75 & 192 & 15.23 & 18.84 \\
\hline State & $\mathrm{N}^{*}$ & $\mathrm{P}$ & $\mathrm{K}$ & $\mathrm{Ca}^{*}$ & $\mathrm{Mg}$ & $\mathrm{Na}^{*}$ & $\mathrm{~S}$ & $\mathrm{Fe}$ & $\mathrm{Cu}^{*}$ & $\mathrm{Mn}$ & $\mathrm{Zn}$ & $\mathrm{B}$ \\
\hline Sick & 2.14 & 0.140 & 2.05 & 1.32 & 0.197 & 0.003 & 0.15 & 75.96 & 3.19 & 281 & 14.61 & 20.22 \\
\hline Healthy & 2.46 & 0.143 & 2.03 & 0.88 & 0.256 & 0.009 & 0.16 & 82.38 & 3.74 & 255 & 15.52 & 17.33 \\
\hline
\end{tabular}

$\mathrm{N}, \mathrm{P}, \mathrm{K}, \mathrm{Ca}, \mathrm{Mg}, \mathrm{Na}$, and $\mathrm{S}: \%$. Fe, Cu, Mn, Zn, and B: $\mathrm{mg} \mathrm{kg}^{-1} .{ }^{*}$ : significant at $P<0.05$.

responses to infections by activation of enzymes in the case of Zn (Humphries et al., 2006; Huber et al., 2012; Gupta et al., 2017; Schumann et al., 2017).

However, the response of plants to these elements is affected to some extent by how they are applied, as well as by changes in $\mathrm{pH}$ and use of chemical molecules as herbicides (Huber et al., 2012; Rahman and Punja, 2007). For Dickeya sp. in plantain cultivation, authors have reported that a $\mathrm{K}$ deficiency predisposes plants to attacks by this pathogen (Bolaños-Benavides and Belalcázar-Carvajal, 2000; Aránzazu et al., 2002; Alarcón and Jiménez, 2012). Consequently, the results coincide with the results reported by BolañosBenavides and Benalcázar-Carvajal (2000). These authors studied the relationship between the attack of bacteriosis and the concentration of nutrients in tissue and soils, finding that, in addition to $\mathrm{K}$, plantain plants affected by disease have low contents of $\mathrm{N}, \mathrm{P}$, $\mathrm{Mn}, \mathrm{B}$, and $\mathrm{Zn}$. Moreover, no correlation between the concentration of nutrients in soil and plant tissues was found.

Physiologically, $\mathrm{K}$ is essential to metabolic processes and influences membrane potential, cell turgor, carbohydrate translocation, protein synthesis, osmoregulatory activities and enzyme catalysis (Mengel, 2007; Pyo et al., 2010). Its importance has been demonstrated because its deficiency facilitates the entry and development of pathogens through physical and metabolic changes that counteract the natural defense mechanisms of plants (Amtmann et al., 2008).

The influence of $\mathrm{N}$ on susceptibility to diseases is related to the metabolic aspects of plants, the effect on the virulence of phytopathogenic microorganisms, and abiotic and biotic factors (Huber and Thompson, 2007). However, results may be inconsistent because it has not been clearly established whether the effect presents when the nutrient supply is low, optimal or excessive, if the effect depends on the form of $\mathrm{N}$ supplied (ammonium or nitrate that are metabolized differently), or if there are differences between infection patterns of obligate and facultative parasites (Huber et al., 2012). Although excess $\mathrm{N}$ is related to attacks by pathogens, mainly foliar, the susceptibility of plants to bacterial spots caused by a facultative parasite decreases with an increase in $\mathrm{N}$ supply, as reported for Xanthomonas vesicatoria in tomato plants (Huber et al., 2012).

On the other hand, the results observed in the current research for the concentration of foliar $\mathrm{Cu}$ in the plants without moko symptoms coincide with the results reported by Bautista-Montealegre et al. (2016), who found a low probability of occurrence of the disease in plants with a high concentration of this element at the leaf level. This response might be due to the effect of $\mathrm{Cu}$ on the lignification of the xylem in photosynthetic processes, in the transfer of electrons and oxidative proteins, as well as in the synthesis of DNA-RNA (Evans et al., 2006; Broadley et al., 2012). There is some uncertainty about the effect of $\mathrm{Na}$ as a nutrient and as a disease suppressant, partly because of the semantics of "essentiality" (Reid et al., 2001; Gorham, 2006), and it is only considered a beneficial nutrient when it influences the stimulation of growth and interaction with other nutrients (Gorham, 2006). However, excess $\mathrm{Na}$ in soil and plants causes restricted growth of the root, marginal burning, or at the tip, of leaves, inhibition of flowering and reduction of crop yield (Greenway and Munns, 1980). Conversely, positive effects are attributed to the control of diseases caused by vascular-type soil pathogens by decreasing damage and increasing dry matter production (Reid et al., 2001; Okada and Matsubara, 2012; Matsubara et al. 2015). 


\section{CONCLUSION}

All evaluated farms in the Department of Cundinamarca registered incidences of 63 and 14\% for bacteriosis and moko, respectively, with the highest presence in the municipalities of Viota and La Vega.

The information collected on the diseases evaluated in the municipalities did not show a defined distribution pattern, and their dispersion was possibly influenced by the soil fertility and the nutritional status of the plants, as well as by the epidemiological aspects and management practices carried out by the plantain producers.

The farm soils cultivated with plantain in the four municipalities of Cundinamarca had an extreme to strong acidity and low effective cation exchange capacity; moreover, the non-saline soils had low concentrations of most elements. The plantain plants had a deficit of elements such as nitrogen, phosphorus, sulfur, copper, zinc, and boron.

Soils from the plantain farms with low concentrations of sulfur and zinc reported the presence of bacteriosis and moko, respectively. The plants free of bacteriosis showed a higher concentration of potassium and lower concentrations of calcium and manganese; while the plants free of moko showed higher concentrations of nitrogen, sodium, and copper and a low concentration of calcium.

The spatial distribution analysis of the bacterial diseases can contribute to the planning of management strategies on a large scale to reduce the risk of dissemination of phytosanitary problems of economic importance in plantains, such as bacteriosis and moko.

Although the incidence of moko in plantain in the Department of Cundinamarca was low (14\%), as compared to bacteriosis (64\%), attention should be paid to this disease because, if adequate control measures are not implemented, Musaceae productivity in the studied municipalities may be compromised.

Nonetheless, it is recommended that the exploratory scale or number of evaluated farms be expanded to more precisely determine the distribution of bacteriosis and moko, as well as the current phytosanitary situation of plantain production systems in the main producing municipalities of the Department of Cundinamarca.
The soil and nutritional requirements of plantain must be analyzed to implement nutritional management of this productive system in the Department of Cundinamarca since a nutritional imbalance in the soil matrix and a deficiency of some nutrients in the plants can influence tolerance to bacteriosis and moko.

Local entities in the municipalities of La Vega, Viota, Chaguani, and La Palma should work jointly with producers in the adoption of recommended integrated diseases management schemes to reduce the impact on plantations.

\section{ACKNOWLEDGMENT}

The results presented in this study are part of the subproject "Validation of available technological strategies for plantain and cassava crops through the implementation of the PIPA methodology in the department of Cundinamarca," which was supported by Convenio Especial de Cooperación Derivado 2. Corredor Tecnológico Agroindustrial (CTA-2) SCTeI No. 022 of 2013; "Research, development and technology transfer in the agricultural and agro-industrial sector in order to improve the entire department, Cundinamarca, Center West" with financing from Sistema General de Regalías [General Royalty System] of the Secretaría de Ciencia, Tecnología e Innovación of the Department of Cundinamarca, the City Hall of Bogotá through the Secretaría de Desarrollo Económico and Contrapartidas of the Universidad Nacional de Colombia and Corporación Colombiana de Investigación Agropecuaria (AGROSAVIA). Many thanks to the plantain producers who are part of this subproject for their cooperation, as well as to the City Halls and UMATAs of the municipalities of Chaguani, La Palma, La Vega, and Viota.

Conflict of interests: The manuscript was prepared and reviewed with the participation of the authors, who declare that there exists no conflict of interest that puts at risk the validity of the presented results.

\section{BIBLIOGRAPHIC REFERENCES}

Agronet. 2020. Evaluaciones Agropecuarias del Sector Agropecuario - EVA y Anuario Estadístico del Sector Agropecuario. Red de Información y Comunicación del Sector Agropecuario de Colombia. Ministerio de Agricultura y Desarrollo Rural de Colombia. Bogota. 
AGROSAVIA, Corporación Colombiana de Investigación Agropecuaria. 2020. Sistema Experto MAPA: Sistema de apoyo a la toma de decisión agroclimáticamente inteligente. Modulo A: Caracterización y análisis de variabilidad climática a escala departamental. In: https://www.agrosavia.co/productos-y-servicios/sistemas-de-informaci\%C3\%B3n; consulted: June, 2020.

Alarcón, J. and J. Jiménez. 2012. Manejo fitosanitario del cultivo del plátano (Musa spp.). Medidas para la temporada invernal. Instituto Colombiano Agropecuario (ICA), Bogota.

Álvarez, E., A. Pantoja, L. Gañán, and G. Ceballos. 2015. Current status of Moko disease and black sigatoka in Latin America and the Caribbean, and options for managing them. CIAT publication No. 404. Centro Internacional de Agricultura Tropical (CIAT); Food and Agriculture Organization of the United Nations (FAO). Cali, Colombia.

Álvarez, E., G. Llano, J. Loke, L. Meza, and V. Triviño. 2007. Manejo de moko de plátano en el eje cafetero de Colombia. Volante informativo CIAT-ICA, Cali, Colombia.

Amtmann, A., S. Troufflard, and P. Armengaud. 2008. The effect of potassium nutrition on pest and disease resistance in plants. Physiol. Plant. 133(4), 682-691. Doi: 10.1111/j.1399-3054.2008.01075.x

Aránzazu, F., J. Valencia, M. Arcila, C. Castrillón, M. Bolaños, P. Castellanos, J. Pérez, and J. Rodríguez. 2002. E1 cultivo de plátano, manual técnico. Corporación Colombiana de Investigación Agropecuaria - Corpoica, Manizales, Colombia.

Bautista-Montealegre, L., G. Fischer, M. Bolaños-Benavides, and J. Arguelles. 2017. Efecto de cuatro nutrientes sobre antracnosis en mora bajo condiciones de invernadero. pp. 87-88. In: Proc. 33 Congreso Colombiano de Fitopatología y Ciencias Afines. Palmira, Colombia.

Bautista-Montealegre, L., M. Bolaños-Benavides, C. Abaunza-González, J. Argüelles-Cárdenas, and C. Forero-Camacho. 2016. Moko of plantain and its relationship with physical and chemical properties in soils of the department of Quindio, Colombia. Rev. Colomb. Cienc. Hortic. 10(2), 273-283. Doi: 10.17584/ rcch.2016v10i2.5066

Bejarano, A. 2010. El moko del plátano en el departamento del Quindío. Últimos avances en la tecnología del cultivo del plátano en Colombia. Corporación Colombiana de Investigación agropecuaria - Corpoica. C. I. Libertad, Villavicencio, Colombia.

Belalcázar, S. 1991. El cultivo del plátano (Musa AAB Simmonds) en el trópico. Instituto Colombiano Agropecuario; Centro Internacional de Investigaciones para el Desarrollo; Comité Departamental de Cafeteros del Quindío; Cali, Colombia.

Bolaños, M. 2006. Actividad enzimática (deshidrogenasa, proteasa, celulasa, fosfatasa y arilsulfatasa) en suelo rizosférico de plátano (Musa AAB): relación con propiedades de un Andisol. PhD thesis. Universidad Nacional de Colombia, Palmira, Colombia.
Bolaños-Benavides, M. and S. Benalcázar-Carvajal. 2000. Relación entre la fertilidad del suelo, el estado nutricional de la planta de plátano y la pudrición del pseudotallo (Erwinia chrysantemi). In: Proc. 14 Reunión de la Asociación para la Cooperación en Investigación de Banano en el Caribe y en América tropical, Acorbat. San Juan, Puerto Rico.

Broadley, M., P. Brown, I. Cakmak, Z. Rengel, and Z. Zhao. 2012. Function of nutrients: micronutrients. pp. 191243. In: Marschner, P. (ed.). Marschner's mineral nutrition of higher plants. Elsevier, San Diego, CA.

Cardona, W., E. Silva, C. Ospina, and M. Bolaños. 2017. Innovación metodológica de diagnóstico participativo para identificar limitantes asociadas al sistema productivo de plátano en el departamento de Cundinamarca (Colombia). pp. 79-80. In: Memoria Tecnológica y Científica IV Congreso Latinoamericano y del Caribe de Plátanos y Bananos; XVIII Congreso Nacional Mexicano de Productores de Plátano; XII Reunión del Comité Directivo de MUSALAC. Tecomán, México.

Castañeda, D. and J. Espinosa. 2005. Comportamiento e impacto de la enfermedad de Moko en la zona de Urabá (Colombia), en las últimas tres décadas y media y propuesta de un índice de riesgo de la enfermedad. Rev. Facultad Nacional de Agronomía Medellín. 58(1), 2587-2599.

Chaboussou, F. 1967. La trophobiose ou les rapports nutritinnels entre la Plante-hôte et ses parasites. Ann. Soc. Ent. Fr. 3 (3), 797-809.

Evans, I., E. Solberg, and D. Huber. 2006. Copper and plant disease. pp. 177-188. In: Datnoff, L.E., W. Elmer, and D. Huber (eds.) Mineral nutrition and plant disease. APS Press, St. Paul, MN.

Gorham, J. 2006. Sodium. In: Barker, A. and D. Pilbeam (eds.). Handbook of plant nutrition. Taylor and Francis, New York, NY.

Greenway, H. and R. Munns. 1980. Mechanisms of salt tolerance in nonhalophytes. Ann. Rev. Plant Physiol. 31, 149-169. Doi: 10.1146/annurev.pp.31.060180.001053

Gupta, N., S. Debnath, S. Sharma, P. Sharma, and J. Purohit. 2017. Role of nutrients in controlling the plant diseases in sustainable agriculture. In: Meena, V., P. Mishra, J. Bisht, and A. Pattanayak (eds). 2017. Agriculturally important microbes for sustainable agriculture. Springer, Singapore. Doi: 10.1007/978-981-10-5343-6_8

Hawkesford, M., W. Horst, T. Kichey, H. Lambers, J. Schjoerring, I. Moller, and P. White. 2012. Functions of macronutrients. In: Marschner, P. (ed.). 2012. Marschner's mineral nutrition of higher plants. Elsevier, San Diego, CA. Doi: 10.1016/B978-0-12-384905-2.00006-6

Huber, D. 1997. Manejo de la nutrición para el combate de patógenos de plantas. Agron. Costarric. 21(1), 99-102.

Huber, D. and I. Thompsom. 2007. Nitrogen and plant disease. 31-43. In: Datnoff, L., W. Elmer, and D. Huber. 2007. Mineral nutrition and plant disease. The American Phytopathological Society. Saint Paul, MN. 
Huber, D., W. Römheld, and M. Weinmann. 2012. Relationship between nutrition, plant diseases and pests. 283-298. In: Marschner, P. (ed). Marschner's mineral nutrition of higher plants. Elsevier, San Diego, CA. Doi: 10.1016/B978-0-12-384905-2.00010-8

Humphries, J., J. Stangoulis, and D. Graham. 2006. Manganese. In: Barker, A. and D. Pilbeam (eds.). Handbook of plant nutrition. Taylor and Francis. New York, NY.

Hurtado, R. 2012. Caracterización de síntomas de la enfermedad de moko en invernadero y campo cuando se simulan labores que causen heridas en plantas de banano y plátano. Tech. Bull. 4 CENIBANANO, Bogota.

ICA, Instituto Colombiano Agropecuario. 1992. Fertilización en diversos cultivos: Quinta aproximación. Manual de Asistencia Técnica 25. Bogota.

IGAC, Instituto Geográfico Agustín Codazzi. 1999. Estudio general de suelos y zonificación de tierras del departamento de Cundinamarca, Tomo I. Bogota.

Jones, D. 2018. Rhizome and pseudostem bacterial rots. pp. 329-339. In: Jone, D. (ed.). Handbook of diseases of banana, abacá and enset. CABI International, Boston, MA.

Kado, C. 2016a. Macerative diseases and their pathogens. pp. 103-130. In: Kado, C. (ed.). Plant bacteriology. The American Phytopathological Society, Saint Paul, MN.

Kado, C. 2016b. Vascular wilt diseases and their pathogens. pp. 131-167. In: Kado, C. (ed.). Plant bacteriology. The American Phytopathological Society, Saint Paul, MN. Doi: 10.1094/9780890545034

Martínez, G. and R. García. 2003. Manejo de la enfermedad del moko o ereke en el cultivo del plátano para la Orinoquia colombiana. Bull. 9. Corporación Colombiana de Investigación Agropecuaria, Villavicencio, Colombia.

Matsubara, Y., J. Liu, and T. Okada. 2015. Effect of $\mathrm{NaCl}$ on tolerance to Fusarium crown rot and symbiosis-specific changes in free amino acids in mycorrhizal asparagus. In: Meghvansi, M. and A. Varma (eds). Organic amendments and soil suppressiveness in plant disease management. Soil Biology 46. Springer, Cham, Germany. Doi: 10.1007/978-3-319-23075-7_25

McMahon, P. 2012. Effect of nutrition and soil function on pathogens of tropical tree crops. Plant Pathology. Dr. Christian Joseph Cumagun, IntechOpen. Doi: $10.5772 / 32490$

Méndez, M. and S. Viteri. 2007. Alternativas de biofertilización para la producción sostenible de cebolla de bulbo (Alium cepa) en Cucaita, Boyacá. Agron. Colomb. 25(2), 168-175.

Mengel, K. 2007. Potassium. pp. 91-116. In: Barker, A. and D. Pilbeam (eds.). Handbook of plant nutrition. Taylor and Francis, New York, NY.

Munson, R. 1998. Principles of plant analysis. pp. 1-24. In: Kalra, Y. (ed). Handbook of methods for plant analysis. CRC Press, Boca Raton, FL. Doi: 10.1201/9781420049398.ch1
Okada, T. and Y. Matsubara. 2012. Influence of arbuscular mycorrhizal fungi and sodium chloride on Fusarium root rot and antioxidative abilities in asparagus plants. J. Japan. Soc. Hort. Sci. 81(3), 257-262. Doi: 10.2503/jjshs1.81.257

Paul, X. 1978. Fungicide sulphur. pp. 101-106. In: Proc. Symposium The use of sulphur containing products in agricultura. The sulphur Institute, Seville, $\mathrm{OH}$.

Pyo, Y., M. Gierth, J. Schroeder, and M. Cho. 2010. High-affinity $\mathrm{K}(+)$ transport in Arabidopsis: AtHAK5 and AKT1 are vital for seedling establishment and postgermination growth under low-potassium conditions. Plant Physiol. 153(2), 863-875. Doi: 10.1104/ pp.110.154369

Rahman, M. and Z. Punja. 2007. Calcium and plant disease. 79-93. In: Datnoff, L., W. Elmer, and D. Huber. 2007. Mineral nutrition and plant disease. The American Phytopathological Society. St. Paul, MN.

Ramírez, J.G., A. Jaraba, and P. Buriticá. 2014. Manejo de la pudrición acuosa del pseudo-tallo (Dickeya sp.) en banano (Musa sp.) bajo condiciones de invernadero. Agron. Costarric. 38(2), 83-92.

Reid, C., M. Hausbeck, and K. Kizilkaya. 2001. Effects of sodium chloride on comercial asparagus and of alternative forms of chloride salt on Fusarium crown and root rot. Plant Dis. 85, 1271-1275. Doi: 10.1094/ PDIS.2001.85.12.1271

Schumann, W., T. Vashisth and T. Spann. 2017. Mineral nutrition contributes to plant disease and pest resistance. University of Florida IFAS Extension HS1181. Gainesville, FL.

Velasco, V. 2000. Role of mineral nutrition on plant disease tolerance. Terra 17(3), 193-200.

Viteri, S., M. Méndez, and J. Villamil. 2012. Verification of alternatives for sustainsable onion production (Allium cepa L.) in Cucaita, Boyacá. Agron. Colomb. 30(1), 124-132.

Williams, J. and R. Cooper. 2003. Elemental sulphur is produced by diverse plant families as a component of defence against fungal and bacterial pathogens. Physiol. Mol. Plant Pathol. 63, 3-16. Doi: 10.1016/j. pmpp.2003.08.003

Williams, J., S. Hall, M. Hawkesford, M. Beale, and R. Cooper. 2002. Elemental sulfur and thiol accumulation in tomato and defense against a fungal vascular pathogen. Plant Physiol. 128, 150-159. Doi: 10.1104/ pp.010687

Yabuuchi, E., K. Yoshimasa, O. Hiroshi, I. Yano, H. Hotta, Y. Hashimoto, T. Esaki, and M. Arakawa. 1992. Proposal Burkholderia gen. Nov. and transfer of Seven especies of the genus Pseudomonas homology group II to the genus, with the type species Burkholderia cepacia (Palleroni and Holmes 1981) comb. Nov. Microbiol. Inmunol. 36(12), 1251-1275. Doi: 10.1111/j.13480421.1992.tb02129.x 